\title{
Use of Green Supply Chain Management for Effective Sustainability
}

\author{
Prof. Sonali S. Waje ${ }^{1}$, Prof. Sapana Y. Birla ${ }^{2}$ \\ ${ }^{1,2}$ Lecturer in Information Technology Department, Government Polytechnic Thane
}

Received on: 11 December, 2020, Revised on: 11 January, 2021, Published on: 16 January, 2021

\begin{abstract}
Environmental pollution is the major problem that mankind, every species on this earth faces in present state, the major emission of toxic gases is from vehicles and manufacturing industries. The industries are emitting more lean wastes within their product life cycle process. The major green wastes from their disposal methods have high impact on environment. These wastes have to be reduced or eliminated by practicing suitable supply chain management techniques. Presently the companies don't practice any supply chain process in their organization. The implementation of supply chain could reduce the environmental pressures and wastes of the companies to some extent. GSCM (Green Supply Chain Management) is one of the recent innovations for increasing the capabilities of Supply Chain Management.

Green supply chain management is defined as the process of using environment friendly inputs \& transforming them into outputs that can be reused at the end of their life cycle thus, creating sustainability in traditional supply chain management. A more sustainable supply chain management is also a less wasteful supply chain, and reducing the waste which can lower a total cost of business while also enhancing industry reputation. This is one of many reasons why green supply chain management is important. The purpose of this paper is to briefly review the literature of the green supply chain management (GSCM) over the last few years. The major activities that came out of the literature are: Green operations, Green design, Green manufacturing, Green purchasing, Reverse logistics and waste management. This paper also focuses on key elements to implement GSCM in more effective way. Nowadays in many text mining applications, supportive
\end{abstract}

Keywords - Sustainable supply chain management, Green operations, Green manufacturing, Green purchasing, reverse logistics, waste management, Green design, GSCM.

\section{I-INTRODUCTION}

A s public becomes more aware of environmental issues \& global warming, consumers will ask more questions about products they are purchasing. Industries will have to expect questions about how green their manufacturing processes $\&$ supply chain are, their carbon footprint $\&$ how they recycle [4]. Sustainable development has made incredible progress in establishing environmental \& social sustainability towards operation management \& supply chain. Sustainable development means "Development that meets needs of present without compromising the ability of future generations" Sustainability covers 3 aspects: economic, environmental and social responsibility.

Green supply chain management (GSCM) is about making the entire supply chain more environment-sustainable. Companies may choose to adopt GSCM for many reasons: one may be forced due to laws \& regulations, one may use GSCM to differentiate oneself in a competitive industry by being environment-friendly and lastly one might need to implement it to stay competitive in market. With growing customer awareness \& regulatory norms, industries with 


\section{International Journal of Innovations in Engineering and Science, www.ijies.net}

greener supply chain management practices will have more competitive advantage over industries that are hesitant to embrace GSCM. Hence, across organizations there is a shift in focus of GSCM creating value for both customers and shareholders. Examples like:

1. Dell company saves over $\$ 20$ million annually as result of supply chain \& packaging enhancements. It achieved its goal of becoming carbon neutral by 2008 .

2. Pepsi-Cola saved $\$ 44$ million by changing it from corrugated to reusable plastic shipping containers for 1 liter \& 20-ounce bottles, sustaining \$196million pounds of corrugated material so far. [5]

\subsection{Supply Chain Management}

The Supply Chain is the shipping of materials/products as they move from source to the end customer. The Supply Chain produce value in the form of products and services to the end customers through different processes \& activities, which are performed by the network of industries from the upstream \& downstream linkages. The network, process \& activities may consist of suppliers, manufacturing centers, warehouses, transportation, distribution centers, \& retail outlets of products/services, as well as raw material, workin-process inventory \& finished products that flows between these facilities.

\subsection{Scope of GSCM}

GSCM scope includes the execution \& observation of general environment management programs and controlling practices executed through several R's (Reduce, Re-use, Rework, Refurbish, Reclaim, Recycle, Remanufacture, Reverse logistics, etc.) towards attaining GSCM waste minimization. The waste is nothing but the non-value adding activity, carried out in any operation. The most commonly perceived enemy to environmental protection is the waste produced in manufacturing \& production operations. That is, manufacturing \& production processes are seen as the perpetrators in harming the environment, in the forms of waste generation, ecosystem disruption, and depletion of natural resources. [2]

\section{II-KEY ACTIVITIES IN GREEN SUPPLY CHAIN MANAGEMENT}

\subsection{Green Operations}

Integrating remanufacturing with internal operations in industries is being the key challenge of Green operations. Green manufacturing and remanufacturing are important areas within green operations. The techniques for minimum energy and resource consumption for flow systems are based on 3 fields namely, pinch analysis, industrial energy and energy lifecycle analysis.

Remanufacturing is defined as recycling-integrated manufacturing. Industries that apply remanufacturing typically includes automobiles, electronics and tires. Product recovery refers to the activities intended to reclaim the value of a product at the end of its useful life. These recoveries can be achieved by using the mathematical models by estimating the resource recovery options.

\subsubsection{Remanufacture \& Refurbishment}

Actually before sending the product to recycling, the manufacturer has to see whether the product can be repaired by either replacing parts of the product or by doing cosmetic changes, so that it can be sold in the secondary market as remanufactured goods. But it is also necessary to make sure that the product has never been used by the returning customer, because no matter how well the remanufacturing \& refurbishing process is done it is constrained to be sold in some markets.

Remanufacture and Refurbishment are categorized into five different types: -
1. Repair
2. Refurbishing
3. Remanufacturing
4. Cannibalization
5. Recycling

\subsection{Green Design}

Green design can be understood as the process of designing the environmentally compatible products \& services. Many industries have been acknowledging that good environmental reputation is fundamental for the company's success in the long run and hence are considering to integrate significant environmental improvements during the product or service development. Across the literature, "green design" can also be termed to as Eco-design, design for environment and life-cycle design. Srivastava [3] 


\section{International Journal of Innovations in Engineering and Science, www.ijies.net}

highlights that one of the common approaches to green design is to replace the materials or processes which have negative environmental impact with those items which are less damaging.

Green design can be referred as "Environmentally Conscious Manufacturing and Product Recovery (ECMPRO)". It includes incorporating environmental thinking into new product development. This process in turn includes design, material selection, manufacturing \& delivery process of the product to the customers along with the end-of-life management of the products/services. The root of green design is to design and develop recoverable, reusable and environmentally compatible products.

\subsubsection{Material selection and label advisors}

The material selection guidelines play important role in green design methods because several materials can be combined to form product which have different level of impact on environment, so the companies should be alert while selecting these materials. These material selection guidelines are discussed by different authors which mentioned some principles for material selection:

- Choose abundant, non-toxic materials where possible.

- Chose materials familiar to nature rather than manmade/artificial materials.

- Minimize the number of raw materials used in a product or process.

- Try to use the materials which have an existing recycling infrastructure.

- Use recycled materials where and when possible.

\subsection{Green Manufacturing}

Green manufacturing is an important area within green operations process. It is defined as the production process which makes use of raw materials as an input which are having relatively low environmental impacts \& these are highly efficient and it generate little or no wastes or pollution.

Johansson and Winroth (2009) stated that Green manufacturing aims for continuous improvements of industrial processes and products to reduce or prevent any type of pollution whether it be air, water or land. He also suggested that by these improvements, there is possibility of minimizing risks to life of humans and other species.
Green manufacturing can lead to minimization of raw material cost, increase in the production efficiency and reduces the environmental and occupational safety expenses. The power consumption can be minimized to greater extent by implementing green manufacturing process. Green manufacturing enhances environmental awareness through 3 R's activities (Zhu, et. al.2007)

Many production or manufacturing process changes occur as following: (Atlas \& Florida, 1998):

- The dependence changes on human intervention

- Continuous process is preferred over batch process

- Altering the nature of the steps in production process

- Eliminating the steps in production process

- Changing cleaning processes

\subsection{Green purchasing}

Green purchasing is also termed as Environmental or Green Procurement. Green purchasing is defined as an environmentally responsive purchasing initiative that tries to safeguard whether purchased products or materials meet environmental objectives set by the purchasing firm. It includes reducing the sources of wastage, promoting recycling, reuse, resource reduction, and substitution of materials.

International Green Purchasing Network (IGPN) is an international body which encourages green purchasing activities and is devoted to the spread of environmentfriendly products and service developments. According to IGPN, Green Purchasing, is a process through which, environmentally superior goods \& services are selectively preferred. Green Purchasing is considered to be an effective way of encouraging goods and services that do not have a declining environmental impact. It also helps in improving the consumer's environmental awareness.

\subsection{Reverse Logistics}

Reverse logistics differ from those of traditional logistics. Reverse logistics is defined as a process where a manufacturer accepts formerly shipped products from the point for consumption for probable recycling and remanufacturing. While traditional logistics focuses on forward movement of raw materials, reverse logistics emphases on controlling backward flows of the raw materials. In simpler terms, it involves moving goods from 


\section{International Journal of Innovations in Engineering and Science, www.ijies.net}

their place of servicing, back to their place of manufacturing for re-processing, re-filling, repairs/recycling/waste disposal. [11]

Reverse logistics specifically comes into scene when product returns need to be managed in an effective and cost-efficient manner. This can lead to profits for the company, also result in improved customer service \& higher customer retention. Manufacturers can undertake suitable reverse logistics activity which includes remanufacturing, repair, reconfiguration and recycling, depending upon the product life cycle stage at which the product was returned.

\subsection{Waste management}

Caruso et al. (1993) model a solid waste management system including collection, transportation, incineration, composting, recycling \& disposal, using a locationallocation model supported by planning heuristics. The source-reduction/pollution-prevention (SR/P2) strategy emphases on 'preventing' pollution at the source (in products as well as manufacturing processes) rather than 'removing' it after it has been created. It is the concept of preventing the formation of waste rather than managing it after it is produced (Gupta and Sharma, 1995).

\section{III- KEY ELEMENTS FOR GSCM INITIATIVE}

\subsection{Government Compliance}

The climate change is happening faster and will bring bigger changes faster than expected. Ironically industrial markets and the nature are hitting the boundaries at once, is a sign that we need to find better solutions to be more sustainable. Whether the drive is to comply with the government regulations or to meet the costumer's expectations, companies are finding reasons to go green. Going green does not just impact company's strategy but impacts overall supply chain as well. The focus is not just to attain cleaner water consumption \& alternative energy sources for farms, but to make supply chains more environment- friendly. The efforts toward green and sustainable business practices is the new frontier for Manufacturers \& industries and "Going Green" is the next step in the lean, just-in-time movement.

\subsection{Financial ROI}

The business leaders navigating their companies through the recession of 2009 would look at their supply chains and assess whether their use of global, open supply-chain standards is sufficient to maximize their return on investment (ROI) \& position themselves for profitability by expanding their boundaries. [9] The futures of their businesses depends on it. More importantly, they are planning ahead for working with their trading partners, thinking globally by implementing data sharing with partners everywhere across their operations and supply chains, so they have visibility achievable through standards.

\subsection{Supply Chain Efficiency}

Organizations are assimilating their supply chains to reduce operating costs and improve their customer service. Companies do not often change their business processes and it is these attitudes which allows inefficient processes to continue unchanged causing needless waste and pollution. The most commonly observed rival to environmental protection is manufacturing and production operations because of their waste generation, improper energy consumption etc. Businesses that wanted to switch to a green supply chain from traditional approach should take the opportunity to review all their processes to identify areas where adopting a greener outlook can actually improvise their business \& lessen waste generation. Industries should review each process along the supply chain to identify more environmentally sound approaches that will help treating inefficiencies. Many industries have identified processes where raw materials were wasted, resources are not properly utilized and unnecessary energy consumed due to inefficient equipment. Product companies can adopt different strategies that serve the dual purpose of environmental stewardship and improving business results.

\section{IV-CONCLUSION}

Green Supply Chain Management can decrease the ecological and environmental impact of industrial activity without compromising quality, cost, reliability, performance or energy utilization efficiency. The purpose of this paper is to briefly provide an overview of the Green 


\section{International Journal of Innovations in Engineering and Science, www.ijies.net}

supply chain literature including key terminologies of GSCM. This paper indicates that GSCM has helped to reduce the ecological and environmental side-effects of industrial activity. The key concepts that came out of the GSCM literature over the last few years are the concepts of green design, green operations, reverse logistics, waste management and green manufacturing \& green procurement. Many research practices \& practical applications have focused on buffering the operations function from external impacts, including the natural environment, in order to improve efficiencies, reduce cost and increase the quality of the products. A lot of research is needed to support the evolution in business practice towards green supply chain. Effective approaches for data sharing across supply chain need to be developed.

\section{REFERENCES}

[1] Samir K. Srivastava, Green supply-chain management: A state-of the-art literature review, International Journal of Management Reviews (2007).

[2] Jamal Fortes, Green Supply Chain Management: A Literature Review, Otago Management Graduate Review, Volume 72009.

[3] Gupta, M. (1995). Environmental management and its impact on the operations function. International Journal of Operations and Production Management, 15(8), 34-51.

[4] Giannis T. Tsoulfas, Costas P. Pappis, Environmental principles applicable to supply chains design and operation,Journal of Cleaner Production 14 (2006).

[5] Gyaneshwar Singh Kushwaha, Sustainable development through strategic green supply chain management, I.J.E.M.S., VOL. 1(1): 7-11

[6] Chen-Lung Yang and Chwen Sheu, The effects of environmental regulations on green supply chains, African Journal ofBusiness Management Vol. 5(26), pp. 1060110614, 28 October, 2011

[7] Ashish Kumar Bhateja, Rajesh Babbar, Sarbjit Singh, Anish Sachdeva, Study of Green Supply Chain Management in the Indian Manufacturing Industries: A Literature Review cum an Analytical Approach for the measurement of performance, IJCEM International Journal of Computational Engineering \& Management, Vol. 13, July 2011

[8] Fiksel, J. (1996). Design for environment: Creating eco efficient products and processes. New York: McGraw-Hill.

[9] L. K. Toke, R. C. Gupta, Milind Dandekar, "Green Supply Chain Management; Critical Research and Practices, (2010)

[10] Zhu, Q.H., and Cote, R. (2002). Green supply chain management in China: how and why? The Fifth International Ecocity Conference, Shenzhen, China.
[11] Srivastava, S. K., \& Srivastava, R. K. (2006). Managing product returns for reverse logistics. International Journal of Physical Distribution and Logistics Management, 36, 524-546.

[12] Helen Walker, Lucio Di Sisto and Darian McBain, "Drivers and barriers to environmental supply chain management practices: Lessons from the public and private sectors," (2008)

[13] Sunil Luthra, Vinod Kumar, Sanjay Kumar, Abid Haleem "green supply chain management, barriers to implement GSCM, interpretive structural modeling"green supply chain management, barriers to implement GSCM, interpretive structural modeling technique-An Indian perspective JIEM, 2011 - 4(2): 231-257. 